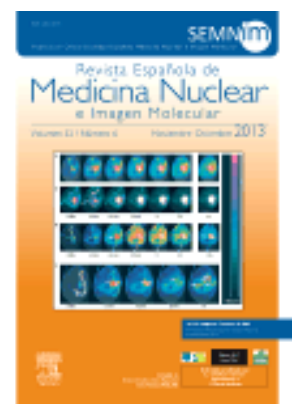

Original article

\title{
Monte Carlo simulation of the basic features of the GE Millennium MG single photon emission computed tomography gamma camera
}

Simulación de Monte Carlo de los rasgos básicos de la cámara gamma SPECT GE Millennium MG

- $\quad \underline{\text { L. Vieira }}{ }^{a,} \underline{b}, \mathbf{A}, \nabla$,

- T.F.Vaz ${ }^{\mathrm{b}}$,

- D.C. Costac,

- $\quad \underline{\text { P. Almeida }}^{\mathrm{a}}$

- $\quad{ }^{a}$ Instituto de Biofísica e Engenharia Biomédica, Faculdade de Ciências, Universidade de Lisboa, Lisboa, Portugal

- $\quad$ Área Científica de Medicina Nuclear, Escola Superior de Tecnologia da Saúde de Lisboa, Instituto Politécnico de Lisboa, Lisboa, Portugal

- ${ }^{c}$ HPP Medicina Molecular, SA, Porto, Portugal 


\section{Abstract}

\section{Objective}

To describe and validate the simulation of the basic features of GE Millennium MG gamma camera using the GATE Monte Carlo platform.

\section{Material and methods}

Crystal size and thickness, parallel-hole collimation and a realistic energy acquisition window were simulated in the GATE platform. GATE results were compared to experimental data in the following imaging conditions: a point source of ${ }^{99 \mathrm{~m}} \mathrm{Tc}$ at different positions during static imaging and tomographic acquisitions using two different energy windows. The accuracy between the events expected and detected by simulation was obtained with the Mann-Whitney-Wilcoxon test. Comparisons were made regarding the measurement of sensitivity and spatial resolution, static and tomographic. Simulated and experimental spatial resolutions for tomographic data were compared with the Kruskal-Wallis test to assess simulation accuracy for this parameter.

\section{Results}

There was good agreement between simulated and experimental data. The number of decays expected when compared with the number of decays registered, showed small deviation $(\leq 0.007 \%)$. The sensitivity comparisons between static acquisitions for different distances from source to collimator $(1,5,10,20,30 \mathrm{~cm})$ with energy windows of $126-154 \mathrm{keV}$ and $130-158 \mathrm{keV}$ showed differences of $4.4 \%, 5.5 \%, 4.2 \%, 5.5 \%, 4.5 \%$ and $5.4 \%, 6.3 \%, 6.3 \%, 5.8 \%, 5.3 \%$, respectively. For the tomographic acquisitions, the mean differences were $7.5 \%$ and $9.8 \%$ for the energy window 126-154 keV and 130$158 \mathrm{keV}$. Comparison of simulated and experimental spatial resolutions for tomographic data showed no statistically significant differences with $95 \%$ confidence interval.

\section{Conclusions}

Adequate simulation of the system basic features using GATE Monte Carlo simulation platform was achieved and validated.

\section{Resumen}

\section{Objetivo}

Describir y validar la simulación de características básicas de la cámara gamma GE Millennium MG utilizando la plataforma GATE Monte Carlo. 


\section{Material y métodos}

El tamaño y espesor del cristal, la colimación de agujeros paralelos y una ventana de adquisición de energía realista se simularon en la plataforma GATE. Los resultados GATE se compararon con los datos experimentales en las siguientes condiciones de formación de imágenes: fuente puntual ${ }^{99 \mathrm{~m}} \mathrm{Tc}$ en diferentes posiciones durante la adquisición de imágenes estáticas y tomográficas utilizando 2 diferentes ventanas de energía. La precisión entre los eventos esperados y detectados por simulación se realizó utilizando la prueba de Mann-Whitney-Wilcoxon. Las comparaciones se hicieron con respecto a las medidas de los parámetros sensibilidad y resolución espacial, estáticas y tomográficas. Las resoluciones espaciales simulada y experimental de los datos tomográficos se compararon con la prueba de Kruskal-Wallis.

\section{Resultados}

Hubo buena concordancia entre los datos simulados y experimentales. El número de decaimientos esperado en comparación con los registrados, ha revelado una pequeña desviación $(\leq 0,007 \%)$. Las comparaciones de sensibilidad entre las adquisiciones estáticas, para diferentes distancias desde la fuente al colimador $(1,5,10,20,30 \mathrm{~cm})$ con ventanas de energía de 126-154 keV y 130-158 keV, mostraron diferencias de 4,4; 5,$5 ; 4,2 ; 5,5 ; 4,5$ y 5,$4 ; 6,3 ; 6,3 ; 5,8$, y $5,3 \%$, respectivamente. Las comparaciones entre sensibilidad tomográfica fueron 7,5 y 9,8\% para la ventana de energía $126-154 \mathrm{keV}$ y 130-158 eV. La comparación de resoluciones espaciales simuladas y experimentales para los datos tomográficos no ha mostrado diferencias estadísticamente significativas con un intervalo de confianza del $95 \%$.

\section{Conclusiones}

Se ha conseguido efectuar y validar una simulación Monte Carlo con la plataforma GATE de características básicas de funcionamiento de una cámara gamma GE Millennium MG.

\section{Keywords}

- Monte Carlo simulation;

- GATE;

- Gamma camera;

- SPECT;

- Static images

\section{Palabras clave}

- Simulación de Monte Carlo;

- GATE;

- Cámara gamma;

- SPECT;

- Imágenes estáticas 